\title{
Experimental Evaluation of Solar/Gas Hybrid- Powered Absorption Air Conditioning System
}

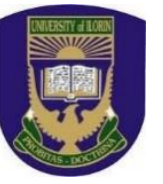

\author{
T. O. Ahmadu*
}

Department of Mechanical Engineering, Faculty of Engineering, Ahmadu Bello University, Zaria, Nigeria.

ABSTRACT: Energy is a vital need of all humans. Space air conditioning using conventional vapour compression systems usually leads to high electricity consumption. There is also the need to safe guard the environment from the harmful emissions of refrigerants used by these systems. In this study an absorption air conditioning system of $3 \mathrm{~kW}$ capacity, operating on the lithium bromide/ water pair was constructed and experimented on a test room. The test scale facility is a hybrid absorption cooling system whose thermal energy requirement was provided by solar energy and an auxiliary Liquefied Petroleum Gas (LPG) burner. Experimental tests were conducted in Zaria in the months of April and June, with each experimental day lasting 9 hours. The peak cooling energy demand of the test room was $1.3 \mathrm{kWh}$. Results from the experiments conducted showed the absorption air conditioning system was able to attain a peak cooling output of $1.5 \mathrm{~kW}$. Maximum Coefficient of Performance (COP) of 0.437 and 0.439 were recorded in the experimental days of April and June respectively. The system achieved space cooling temperatures within $24^{\circ} \mathrm{C}$ to $27^{\circ} \mathrm{C}$. Solar fractions of 0.61 was recorded in April and 0.27 was recorded in June.

KEYWORDS: solar energy, absorption, liquefied petroleum gas, air conditioning system, experimental evaluation, cooling.

\section{INTRODUCTION}

Growing populations and advancing technological developments has led to increase in the demand for energy, especially in developing nations. Increasing occupants indoor comfort demands has led to growth in thermal cooling loads notably during peak periods (Kalkan et al., 2012). Electrically powered mechanical compression chillers are generally employed in the air conditioning of buildings. However these units operate with synthetic refrigerants such as hydro chlorofluorocarbons (HCFCs); which when released into the atmosphere constitute high Ozone Depleting Potential (ODP) (Sarbu and Sebarchievici, 2015). Also, these mechanical compression chillers consume high electric power which increases cost of operation.

There have been increase in the requirements for environmental protection from the harmful effects of these refrigerants. Increase in primary energy prices have led to renewed research attention to thermally driven absorption air conditioning systems which use environmentally friendly refrigerants. The most commonly used absorption chiller is that which operates on the lithium bromide/water pair (Henning, 2007). The heat source temperature is usually within $70-100^{\circ} \mathrm{C}$, therefore have the advantage of being powered by renewable or waste heat. It is expected that primary energy savings as well as environmental protection can be achieved by the use of absorption chillers powered by renewable or waste heat.
Studies on thermally driven absorption air conditioning systems in different places and locations have been undertaken and reported. Balghouthi et al., (2012) reported the performance of a solar powered $16 \mathrm{~kW}$ double effect absorption chiller, in Tunisia. The system was driven by parabolic trough solar collectors and Coefficient of Performance (COP) ranged between 0.8 and 0.9. Sun et al., (2015) evaluated the performance of a hybrid absorption chiller fired by solar and gas in single effect and double effect modes respectively. The system tested in Shandong, China showed a COP of 0.75 . Winston et al., (2014) in the United States investigated the performance of a $23 \mathrm{~kW}$ double effect absorption chiller driven by solar compound parabolic concentrators.

Average daily collector efficiency of $36.7 \%$ was reported as well as COP of 0.99. Ketjoy et al., (2013) experimentally evaluated the performance of a $35 \mathrm{~kW}$ lithium bromide - water absorption chiller for providing cooling under the weather conditions of Thailand. The system was driven by solar power as well as a gas back up system. Average COP of 0.33 and solar fraction of 0.55 were reported. Bermejo et al., (2010) evaluated the performance of a solar/ gas powered absorption cooling system. The system located in Spain obtained a maximum collector efficiency of $40 \%$ and an average daily COP between $1.1-1.25$. In spite of favourable energy savings prospect, solar cooling technology is still somewhat a scarcity, due to their high initial cost and to the lack of knowledge on system 
implementation and expected performance Blackman et al., (2015).

Nigeria, a country located in the Savanah region of West Africa has a vast availability of solar energy. A modest estimate of the technical potential of solar energy in Nigeria with $5 \%$ device efficiency is put at $15 \times 10^{14} \mathrm{~kJ}$ of useful energy annually. This translates to about $4.2 \times 10^{5} \mathrm{GWh}$ of electricity production annually (Oyedepo, 2012). In Nigeria, during the hot months, cooling demand in office buildings increases, especially in the northern states (Oyedepo, 2012, Eke, 2011).

The air conditioning of office buildings are normally met using electrically powered mechanical compression chillers. Despite the huge solar energy potential, there is very little information on the prospect of a solar powered absorption air conditioning system in Nigeria. The present study is therefore intended to evaluate the performance of a constructed experimental solar and gas powered absorption air conditioning plant. The test was carried out in Zaria, Nigeria.

A. System Description

The system referred to herein is a pilot scale $3 \mathrm{~kW}$ capacity, solar/ LPG gas powered absorption air conditioning system. The overall system consists of six major components: a $3 \mathrm{~kW}$ $\mathrm{LiBr} / \mathrm{H}_{2} \mathrm{O}$ absorption chiller, a $4.5 \mathrm{~kW}$ water cooled cooling tower, flat plate collector, hot water tank, an auxiliary gas burner and indoor fan coil unit.

The $2 \mathrm{~m}^{2}$ solar collector was used to provide thermal energy to the water in the storage tank which was then supplied to the absorption chiller within $80^{\circ} \mathrm{C}$ to $95^{\circ} \mathrm{C}$. The absorption chiller uses the hot water to supply the thermal energy required at the generator, chilled water was produced at the evaporator. The LPG gas burner was used to provide thermal energy to the water in the storage tank when the solar radiation was not sufficient to provide thermal energy to required levels.

The absorption chiller was cooled by the $4.5 \mathrm{~kW}$ wet cooling tower. The chilled water produced by the chiller was pumped to the indoor fan coil unit where cooling of the test room takes place. The system was used to air condition a test room in the heat engine laboratory of the Department of Mechanical Engineering, Ahmadu Bello University, Zaria. Fig. 1 shows the outdoor units of the experimental plant consisting of the solar collector, hot water tank, gas burner and cooling tower.

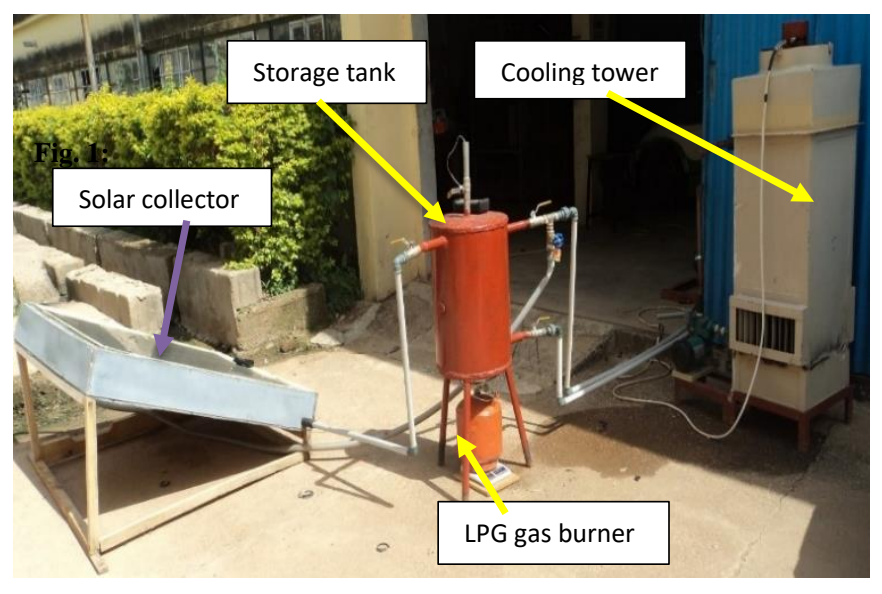

Fig. 1: Experimental plant outdoor units.

\section{1.) The absorption chiller}

The absorption chiller is the main component of the absorption air conditioning system. The single effect absorption chiller which operates on the lithium bromide/ water pair has a nominal cooling capacity of $3 \mathrm{~kW}$. It consists of a generator, condenser, absorber and evaporator which were designed and constructed as shell and tube heat exchangers. It has a double pipe Solution Heat Exchanger (SHX), expansion valves, hot water pump, chilled water pump, solution pump and refrigerant pump. The chiller was hot water fired and chilled water was produced at the evaporator. Fig. 2 shows sections of the absorption chiller.

\section{2.) The solar collector}

A flat plate solar collector was constructed. It consists of a black flat absorber plate, copper tubes connected by header and riser in which water flows, a single glazing. Fibre glass was used as insulator at the back and edges, secured firmly in wooden support.

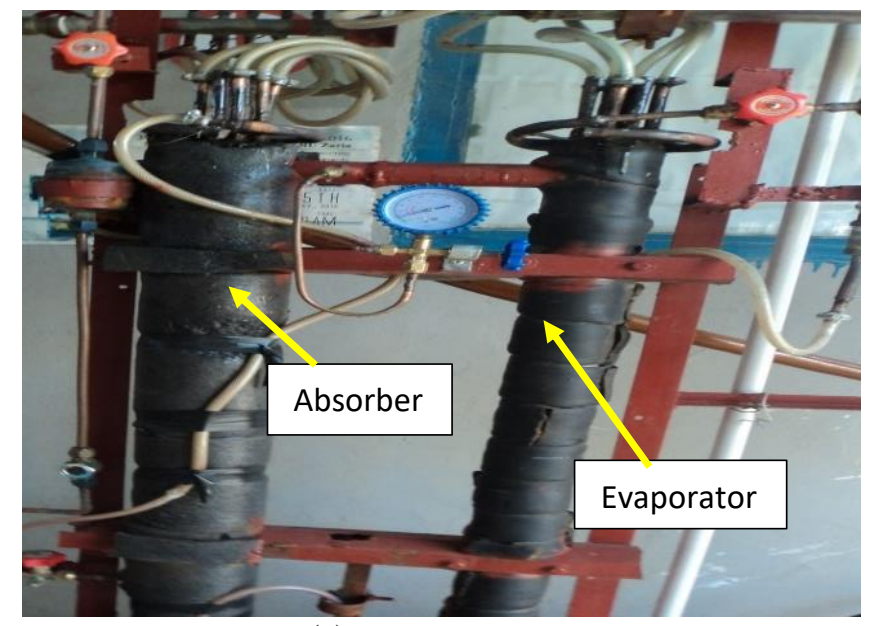

(a)

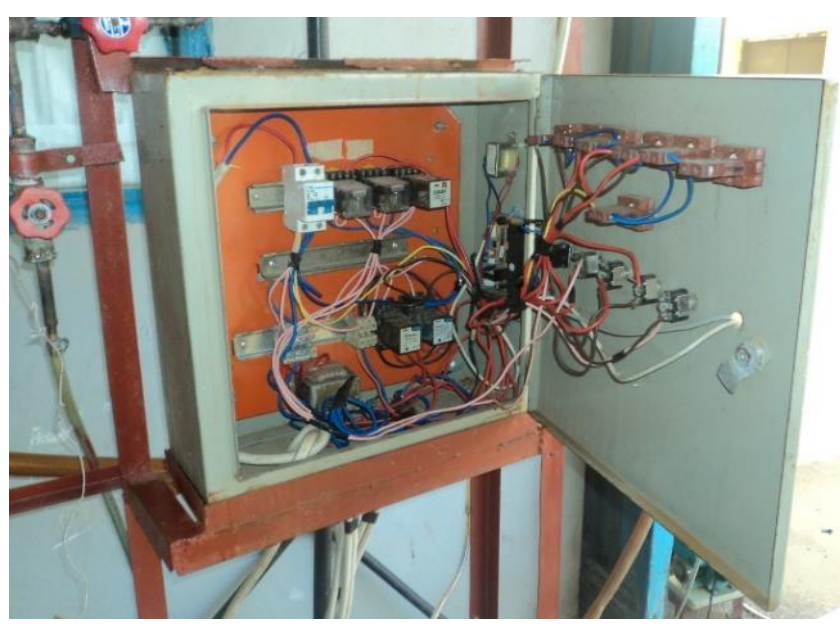

(b)

Fig. 2: The absorption chiller: (a) heat exchangers (b) control panel 


\section{3.) The cooling tower}

The cooling tower was designed and constructed as an induced draft counter flow cooling tower. It was water cooled and consists of a water pump which circulates cooling water between the cooling tower sump and the condenser/ absorber in the absorption chiller. It has water spray distributors, and a cooling fan located at the top of the cooling tower.

\section{4.) The hot water tank/ LPG gas burner unit}

This unit, designed and constructed, has a steel water tank of 40 litres capacity. It serves to supply hot water to the chiller. At the bottom of the tank was located a LPG gas burner, which was turned on to heat the water in the tank when solar radiation is low.

\section{5.) The indoor fan coil unit}

The indoor fan coil unit was placed inside the test room. Chilled water, pumped from the evaporator flows through cooling coils in the fan coil unit. Air is blown over the chilled fan coils by a blower. The resulting cool air is distributed round the room.

\section{B. Experiment}

This section presents the method used in evaluating the test room cooling energy demand. The experimental procedure as well as measuring instruments used are presented. The parameters used in evaluating the system performance are presented as well.

\section{1.) Test room cooling energy demand}

The test room covers a total floor area of $9.21 \mathrm{~m}^{2}$. It consists of two walls of $3.17 \mathrm{~m}$ length and $3 \mathrm{~m}$ high, the other two walls are $2.9 \mathrm{~m}$ length and $3 \mathrm{~m}$ high. Walls are made of bricks with plaster on both sides, while the roof is flat and made of concrete. The room has single glazing windows of $3.24 \mathrm{~m}^{2}$ area. The room was modelled and simulated as a single zone using TRNSYS 16 software to determine the cooling energy demand. This was done by specifying inputs which described the internal space, occupancy, equipment and activity. The desired room temperature and relative humidity were set at $24^{\circ} \mathrm{C}$ and $50 \%$ respectively. The peak cooling load for the test room from TRNSYS simulation was $1.25 \mathrm{~kW}$, this occurred in the month of April. Fig. 3 shows the monthly peak cooling loads as well as the monthly average solar radiation.

\section{2.) Experimental procedure}

The experiments reported here were conducted in the month of April 2017, which is a very hot month in Zaria and in the month of June 2017, which is a rainy month in Zaria. Each of the experimental days span from 8.30 am to $5.30 \mathrm{pm}$. Two heating modes were employed to provide the thermal energy required for the hot water: the solar power heating mode, provided via the solar collector and the gas burner heating mode, provided by liquefied petroleum gas burner. Switching between solar heating and gas heating modes was achieved via a bypass line activated by flow valves. At the start-up of each experimental day, thermal energy was supplied to the water in the tank using the gas burner. This was because solar radiation is usually very low at the early hours of the day to attain heating to required water temperature.

When the required temperature in the tank was attained $\left(90^{\circ} \mathrm{C}-99^{\circ} \mathrm{C}\right)$, the hot water pump was then turned on to circulate the hot water between the tank and the absorption chiller. When the temperature of the collector fluid increased to $80^{\circ} \mathrm{C}$ and above, the gas burner was disengaged and the system was switched to solar heating mode. This was achieved by activating flow valve 2 , while flow valve 1 stays closed. When temperature of the collector fluid drops below $80^{\circ} \mathrm{C}$, the system was switched back to gas burner heating mode. Chilled water was produced at the evaporator and pumped to the fan

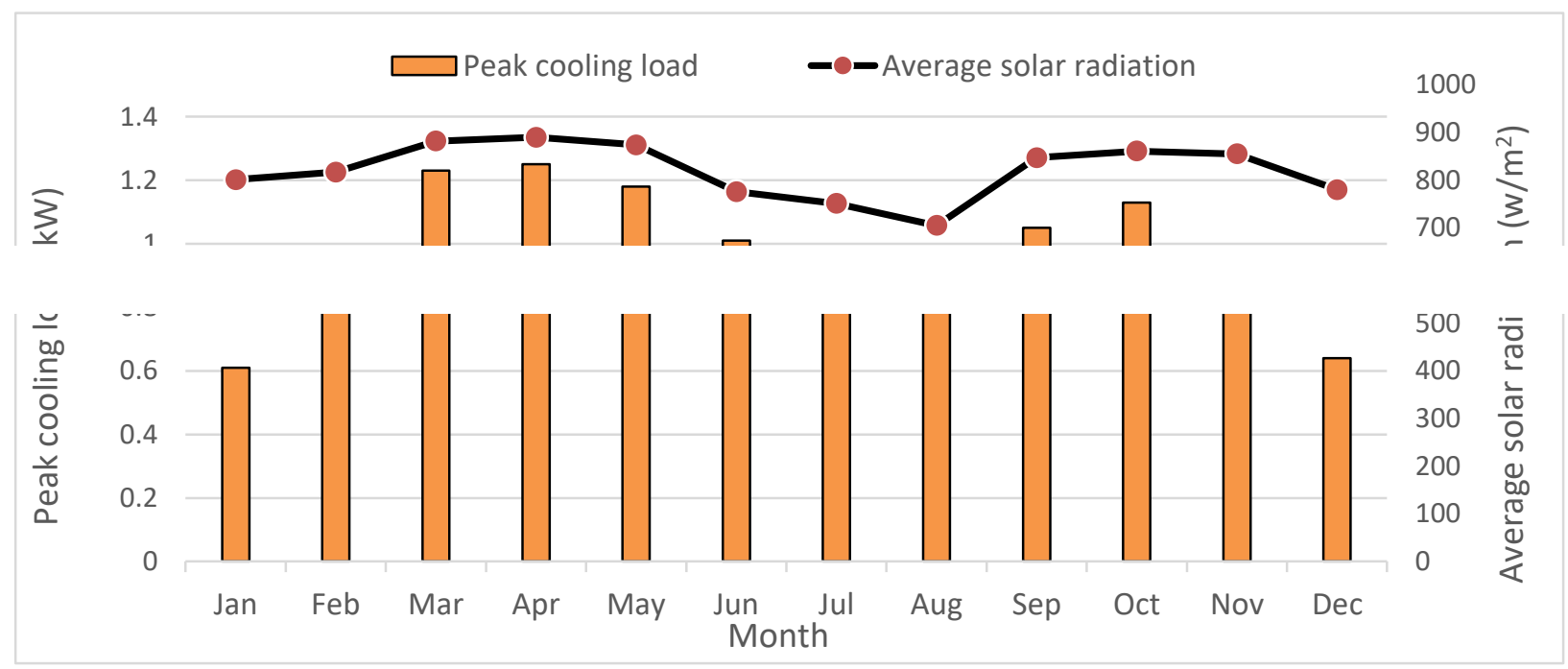

Fig. 3: Monthly peak cooling load and monthly average solar radiation for the test room from TRNSYS simulation. 
coil unit in the test room. Temperature readings were taken every fifteen minutes from sensors attached to the system components and test room. Solar power was measured using a solar meter. Gas consumed was measured by placing the gas burner on a weighing scale and taking measurements as a result of weight loss at intervals. Fig. 4 is a schematic of the experimental set up.

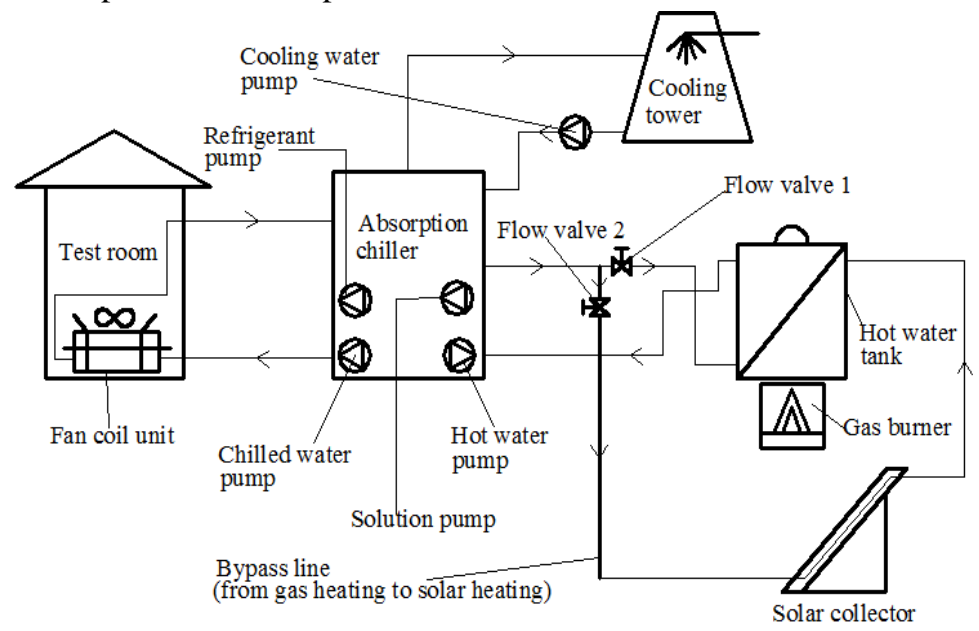

Fig. 4: Schematic of the experimental set up.

\section{3.) Measuring instruments}

The following instruments were used in taking measurements during the experiment:

a) Digital solar power meter: model no.: DBTU 1300 , measuring range: $0-2000 \mathrm{~W} / \mathrm{m}^{2}$, accuracy: $\pm 5 \%$ of reading

b) Digital infrared thermometer: model no.: PM6350D, measuring range: $-50-800^{\circ} \mathrm{C}$, accuracy: $\pm 1.5^{\circ} \mathrm{C}$

c) Digital thermocouple thermometer: model no.: $\mathrm{T} 407291$, measuring range: $-50-1300^{\circ} \mathrm{C}$, accuracy: $0.1 \%+1^{\circ} \mathrm{C}$

d) Watt meter: model no.: H3680W, measuring range: 0 $3680 \mathrm{~W}$, accuracy class: 1.0

e) Digital weighing scale: model no.: $\mathrm{SF}-400$, measuring range: $0-7000 \mathrm{~g}$, accuracy: $\pm 1 \mathrm{~g}$

\section{4.) Performance measurement}

The following performance parameters were obtained:

a) Evaporator cooling power $\left(Q_{e}\right)$ :

$Q_{e}=\dot{m}_{e} C_{p}\left(T_{e 2}-T_{e 1}\right)$

where $\dot{m}_{e}$ is the mass flow rate of chilled water at the evaporator $=0.31 \mathrm{Kg} / \mathrm{s}$

$C_{p}$ is the specific heat capacity of the chilled water

$T_{e 2}$ and $T_{e 1}$ are the outlet and inlet chilled water temperatures to the evaporator respectively

b) Generator heat load $\left(Q_{g}\right)$ :

$Q_{g}=\dot{m}_{g} C_{p}\left(T_{g 1}-T_{g 2}\right)$

where $\dot{m}_{g}$ is the mass flow rate of hot water at the generator $=0.25 \mathrm{Kg} / \mathrm{s}$

$C_{p}$ is the specific heat capacity of the hot water
$T_{g 1}$ and $T_{g 2}$ are the inlet and outlet hot water temperatures to the generator respectively.

c) Collector efficiency $\left(\eta_{c}\right)$ :

The collector efficiency was calculated according to Duffie and Beckman (2013) as:

$\eta_{c}=\frac{\dot{m}_{c} C_{p} \Delta T}{A_{c} G_{T}}$

where $\dot{m}_{c}$ is the mass flow rate of fluid at the collector $=0.1 \mathrm{~kg} / \mathrm{sec}$

$\Delta T$ is the fluid temperature difference between inlet and outlet to the collector

$A_{c}$ is the area of the collector

$G_{T}$ is the solar radiation on the collector surface

d) Solar power used $\left(P_{\text {solar }}\right)$ :

The solar power is defined as:

$P_{\text {solar }}=A_{c} G_{T}$

e) Gas consumption $\left(P_{\text {gas }}\right)$ :

The weight of gas consumed at an interval of time was determined by weight difference over the time interval using a digital weighing scale. The gas consumption in $\mathrm{kW}\left(P_{\text {gas }}\right)$ is:

$P_{\text {gas }}=\frac{m \mathrm{Cal}_{\mathrm{g}}}{t}$

where:

$m$ is the weight of the gas consumed in the time interval $(\mathrm{kg})$

$\mathrm{Cal}_{g}$ is the calorific value of liquefied petroleum gas taken as $46.1 \mathrm{MJ} / \mathrm{kg}$ (Demirel, 2012)

$t$ is the time interval (in seconds) in which the gas was used

f) Coefficient of Performance (COP):

The COP was computed as:

$C O P=\frac{Q_{e}}{Q_{g}}$

g) Solar Coefficient Of Performance (SCOP):

The SCOP gives an overall efficiency value of the solar cooling installation. The SCOP was computed as:

$S C O P=\eta_{c} C O P$

h) Solar Fraction:

This was calculated by dividing the number of hours in which the chiller was fired in solar heating mode by the total number of hours of chiller operation for the experimental day.

\section{RESULTS AND DISCUSSION}

The results presented in this paper are for the experimental days of April 22 $2^{\text {nd }}, 2017$, which was classified as a hot clear sky day with high solar radiation and June $8^{\text {th }}, 2017$, which was classified as a cloudy sky day with average solar radiation. Fig.s 5 to 9 show results from the experimental day of April $22^{\text {nd }}, 2017$. 
From Fig. 5 high solar radiation can be seen to have been recorded, with radiation in excess of $1000 \mathrm{~W} / \mathrm{m}^{2}$ recorded between 11 and $14 \mathrm{hrs}$. Solar radiation however drops from 15 hrs to the close of the experimental day.

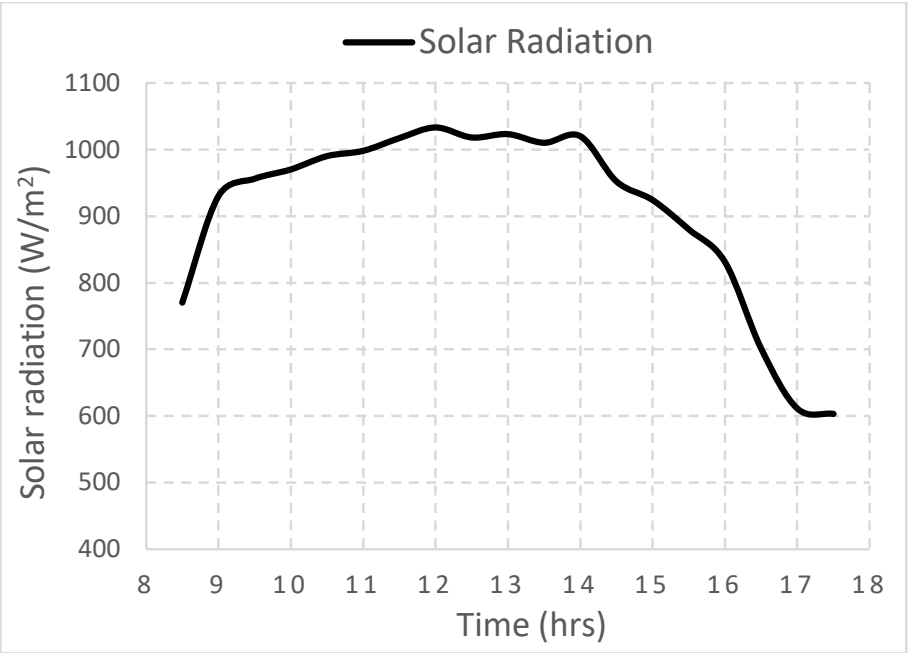

Fig. 5: Variation of solar radiation with time for April $2^{\text {nd }}$.

From Fig. 6, the hot water tank fluid temperature is observed to have risen from below $40^{\circ} \mathrm{C}$ at $8: 30 \mathrm{hrs}$ to above $90^{\circ} \mathrm{C}$ at 9:30 hrs, this was as a result of thermal energy supplied in gas burner heating mode. Generator temperatures can be seen to be above $80^{\circ} \mathrm{C}$ between 10:00 hrs to $12: 00 \mathrm{hrs}$, however, from 12:00 hrs, generator and tank temperatures are seen to decline until it gets to a low at 15:00 hrs. This was because the system was fired in the solar heating mode within this interval.

As the day progresses, solar radiation becomes weaker, leading to lower thermal energy to the hot water tank fluid; which causes reduced generator temperatures. Low generator temperatures causes weak evaporation process, leading to rise in evaporator chilled water temperatures. Generator and tank temperatures increase again after 15:00 hrs. This is because the system was switched back to gas burner heating mode, and the required thermal energy was obtained. Evaporator chilled water outlet temperature is observed to drop from about $24^{\circ} \mathrm{C}$ at the start of chilling at $10: 00 \mathrm{hrs}$ to below $20^{\circ} \mathrm{C}$ during the experiment. This indicates that chilling was obtained at the evaporator.

Cooling power between $0.9 \mathrm{~kW}$ and $1.45 \mathrm{~kW}$ can be observed to have been achieved between 10:00 hrs and 17:00 hrs as seen in Fig. 7. The low cooling power recorded between 14:30hrs to $15: 30 \mathrm{hrs}$ results from the low generator temperatures and rise in evaporator chilled water temperatures recorded in this interval. Gas burner heating mode was employed between 8:30 hrs to 10:00 hrs and between 15:30 hrs to 17:30 hrs. This is due to low solar radiation at these times. Electric power consumption was constant at $0.5 \mathrm{~kW}$ for the experimental day.

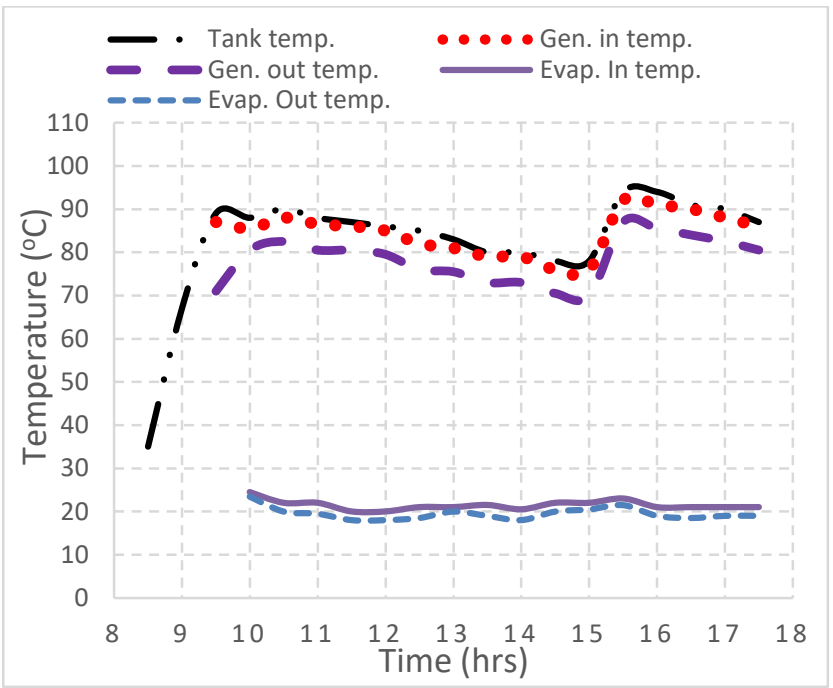

Fig. 6: Variation of system temperatures with time for April $22^{\text {nd }}$.

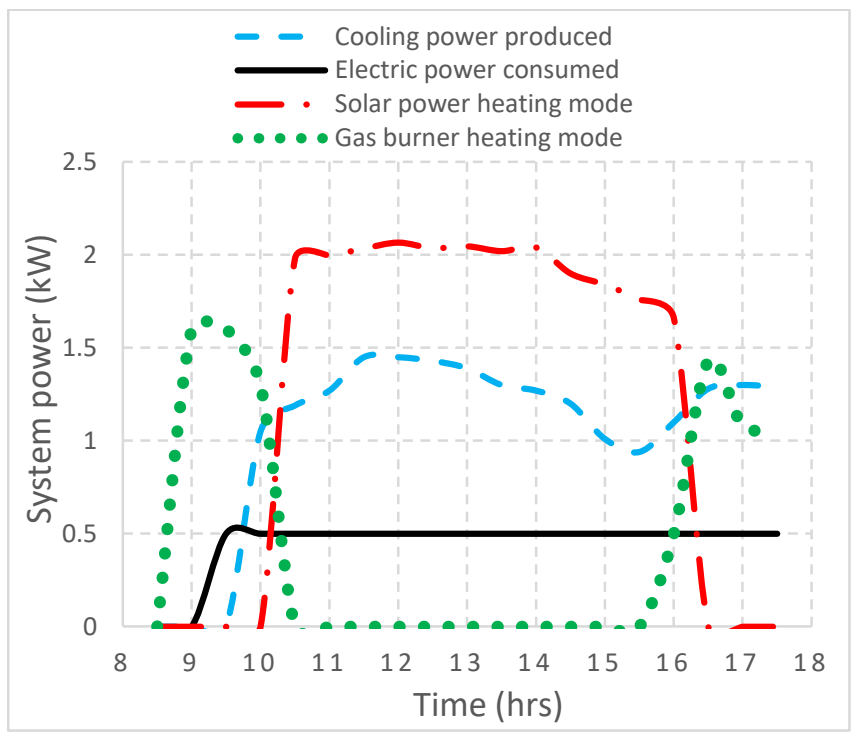

Fig. 7: Variation of system power with time for April $22^{\text {nd }}$.

Fig. 8 shows the variation of ambient and room temperature with time. The room temperature is observed to be above $30^{\circ} \mathrm{C}$ and above the ambient temperature between 8:30 hrs to 9:45 hrs, this was before the commencement of cooling. On commencing cooling, room temperature is seen to drop well below the ambient temperature. This is an indication that cooling was achieved. Room temperatures between $24^{\circ} \mathrm{C}$ and $27^{\circ} \mathrm{C}$ were recorded. Evaporator chilled water outlet temperatures are seen to be below $21^{\circ} \mathrm{C}$. 


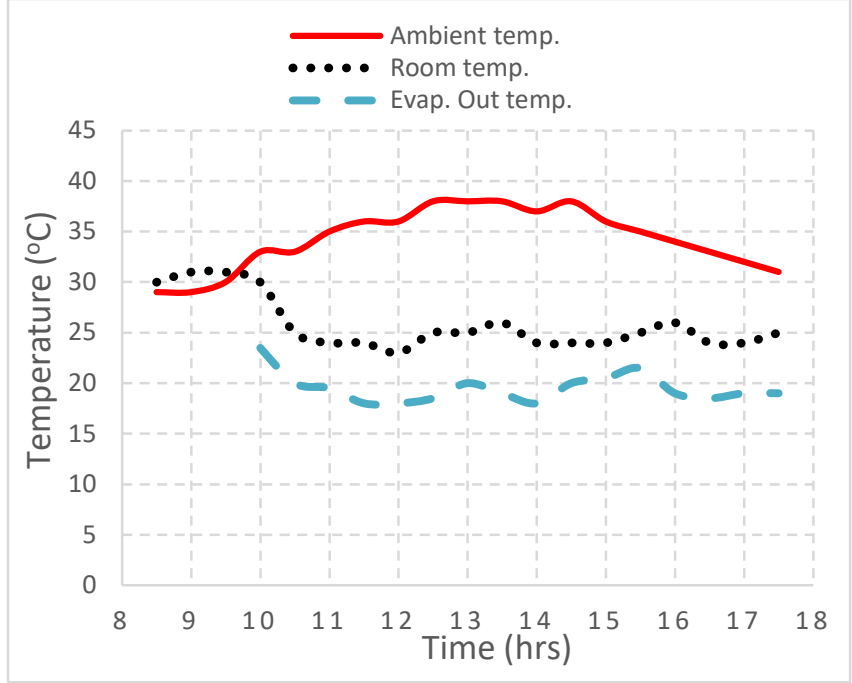

Fig. 8: Variation of ambient and room temperature with time for April $22^{\text {nd }}$.

From Fig. 9, COP between 0.27 and 0.439 were recorded between 10:00 hrs and 17:30 hrs, while SCOP of between 0.05 and 0.15 were recorded within the same time interval. The low COP observed between 14:30 hrs and 16:00 hrs was as a result of drop in solar radiation at this time which caused low thermal energy supply and weak evaporator cooling power.

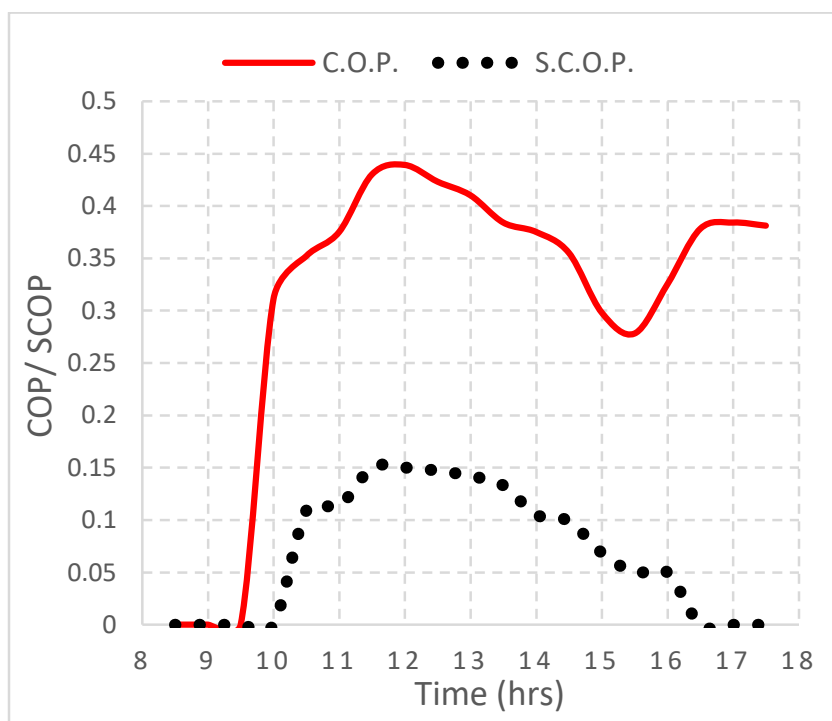

Fig. 9: Variation of COP and SCOP with time for April 22 ${ }^{\text {nd }}$.

Fig.s 10 to 14 show the results from the experimental day of June $8^{\text {th }}, 2017$. As observed from Fig. 10, solar radiation is much lower than $700 \mathrm{~W} / \mathrm{m}^{2}$ for a greater part of the experimental day. This is as a result of the cloudy nature of the day.

From Fig. 11, generator and tank temperatures are seen to be above $80^{\circ} \mathrm{C}$ between 9:30 hrs and 12:00 hrs, the gas burner heating mode was used in this period. Generator and tank temperatures are seen to decline between 12:00 hrs and 14:30 $\mathrm{hrs}$, a period in which the system was operated in solar power

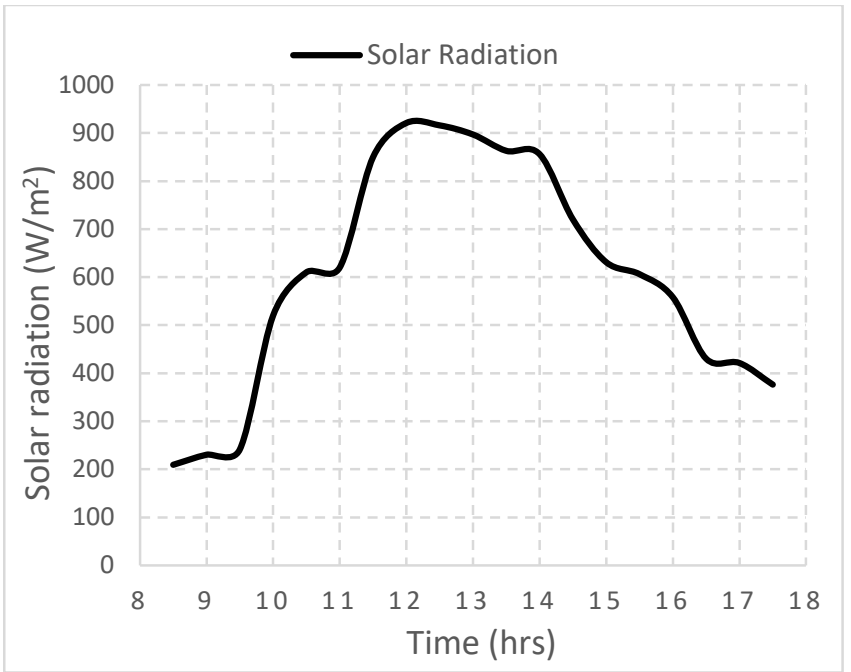

Fig. 10: Variation of solar radiation with time for June $8^{\text {th }}$.

heating mode. This was due to decreasing solar radiation, which decreases thermal energy supply. System was switched to gas burner heating mode at 14:30 hrs, tank and generator temperatures are seen to rise thereafter. Evaporator chilled water outlet temperature is seen to be below $20^{\circ} \mathrm{C}$ during cooling period, an indication that chilling was achieved.

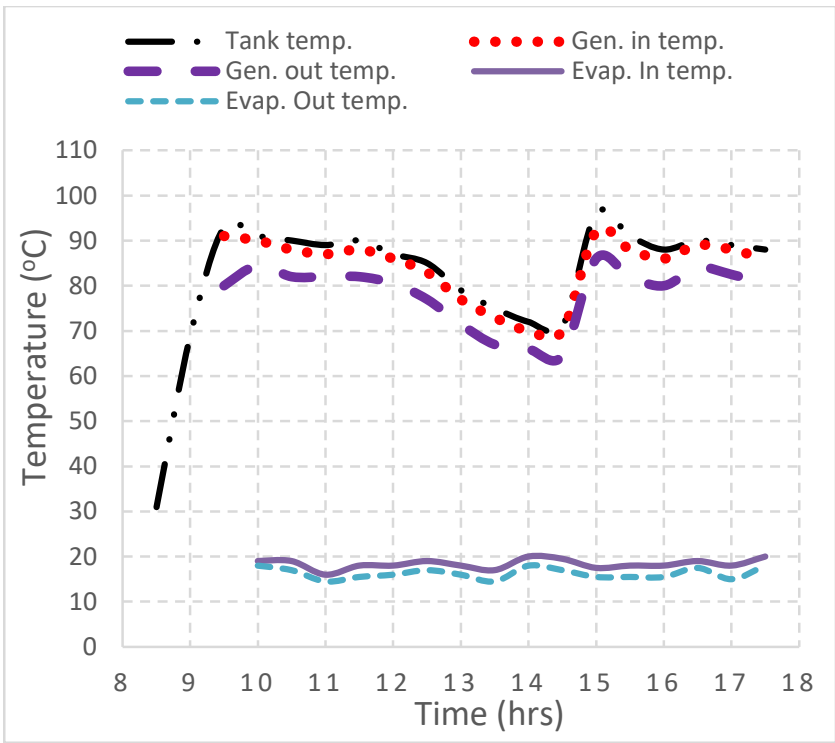

Fig. 11: Variation of system temperatures with time for June $8^{\text {th }}$.

Fig. 12 shows the variation of system power with time. It can be observed that the system was operated in the solar power heating mode only between the hours of 11:30hrs and 14:30hrs, gas burner heating mode was employed for the rest of the day. This was due to the cloudy nature of the day which resulted in low solar radiation for most part of the day. Maximum cooling power of $1.45 \mathrm{~kW}$ was achieved. The drop in cooling power produced between 12:30hrs to 14:00hrs was due to drop in solar power available. 


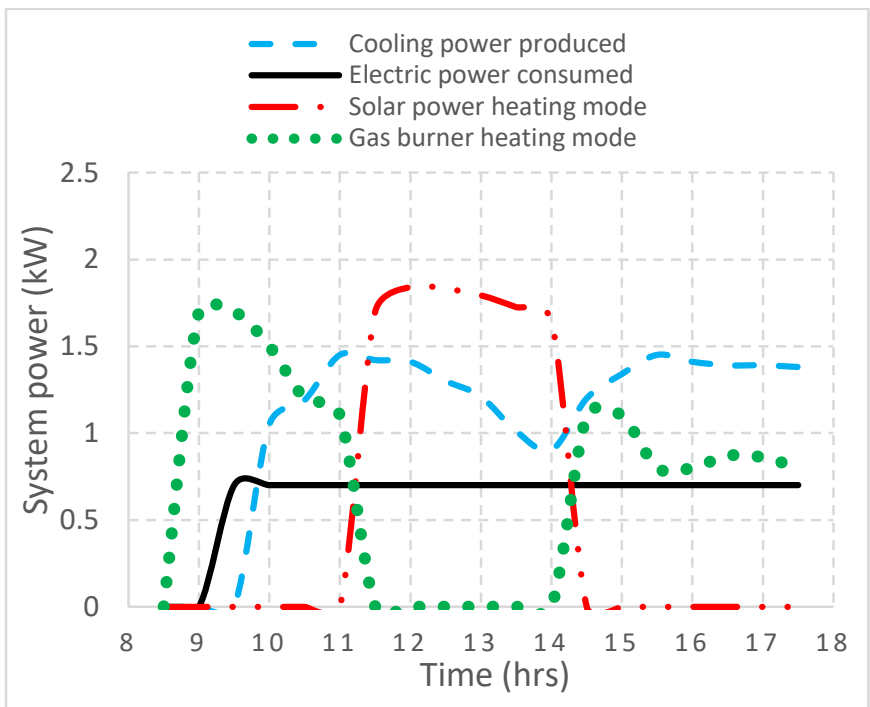

Fig. 12: Variation of system power with time for June $8^{\text {th }}$.

From Fig. 13, room temperature is seen to be above the ambient temperature between 8:30 hrs and 10:00 hrs, this was before cooling commenced. When cooling started, room temperature is observed to drop well below the ambient temperature, an indication that room cooling was achieved. Room temperatures between $24^{\circ} \mathrm{C}$ and $27^{\circ} \mathrm{C}$ were recorded.

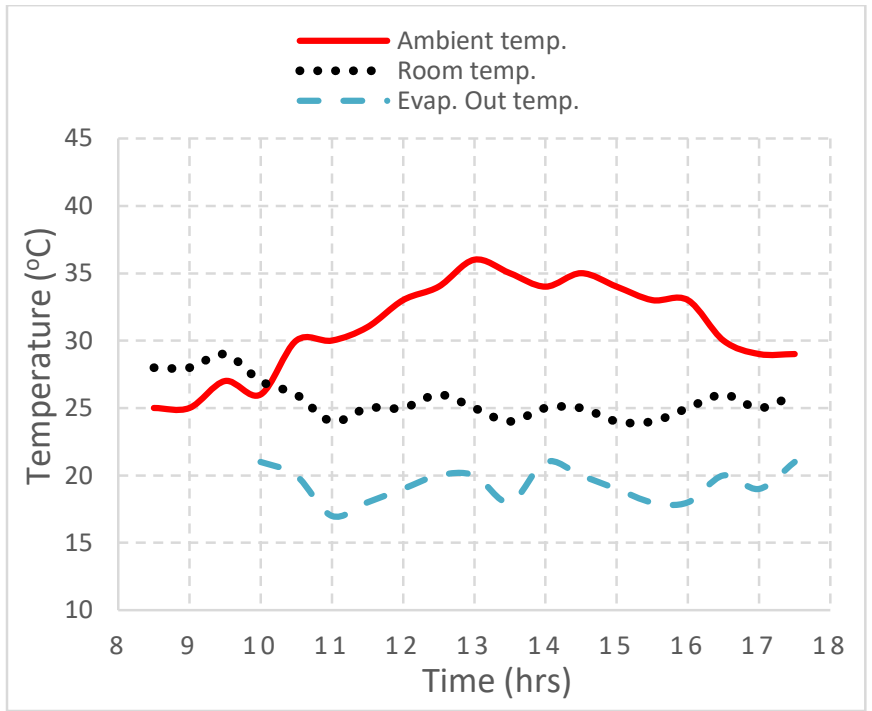

Fig. 13: Variation of ambient and room temperature with time for June $8^{\text {th. }}$.

Fig. 14 shows the variation of COP and SCOP with time. It can be observed that peak COP of 0.429 was achieved at 11:00hrs. COP then declines until its lowest point of 0.265 at 14:00hrs. This is because the system was operated in the solar power heating mode within this period, solar radiation declined and evaporator cooling power dropped. COP however rises again to above 0.4 when system is switched back to gas burner heating mode. This is because higher evaporator powers were attained. SCOP of below 0.1 was recorded.

For the two experimental days recorded, an average room cooling temperature between $24^{\circ} \mathrm{C}$ to $27^{\circ} \mathrm{C}$ was attained. This compares favourably with room cooling temperatures reported in similar works of similar capacity that used the $\mathrm{LiBr} / \mathrm{H}_{2} \mathrm{O}$ pair: (Franchini et al, $2015\left(24^{\circ} \mathrm{C}-26^{\circ} \mathrm{C}\right)$, Yin et al, $2013\left(24^{\circ} \mathrm{C}\right.$ $\left.-27^{\circ} \mathrm{C}\right)$, Gonzalez - Gil et al, $2011\left(23^{\circ} \mathrm{C}-25^{\circ} \mathrm{C}\right)$.

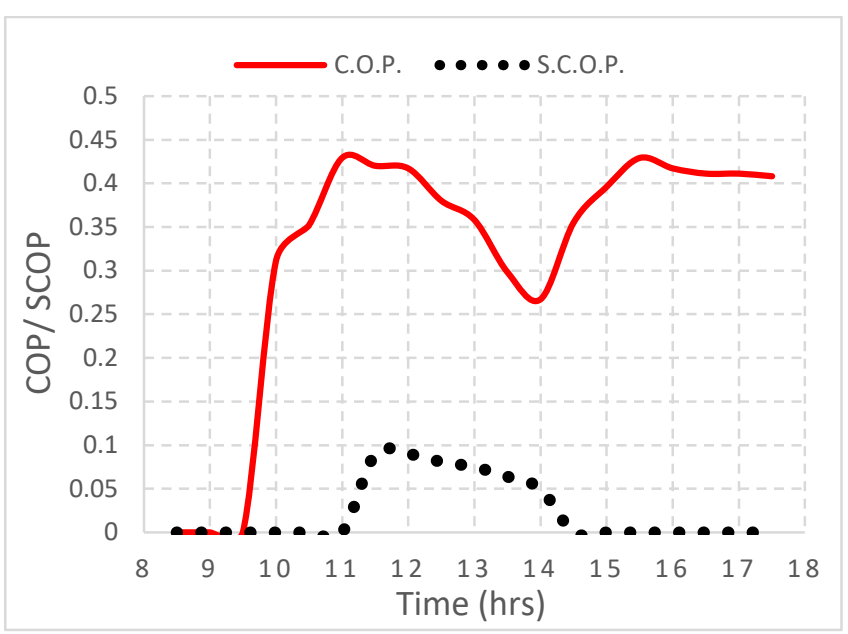

Fig. 14: Variation of COP and SCOP with time for June $8^{\text {th }}$.

Fig. 15 shows measure of performance indicators for the two experimental days reported. As observed from the figure, solar fraction of 0.61 was attained on April 22 $2^{\text {nd }}$, compared to solar fraction of 0.27 on June $8^{\text {th }}$. This is expected, as much higher solar radiation was recorded on April $22^{\text {nd }}$ compared to June $8^{\text {th }}$. The system was therefore able to operate longer on solar power heating mode on April $22^{\text {nd }}$. There is no much difference in the average COP for the two experimental days, with April $22^{\text {nd }}$ recording 0.386 , June $8^{\text {th }}$ recording 0.378 .

This is because the absorption chiller was capable of operating both in the solar power heating mode and gas burner heating mode. Average COP recorded by the constructed chiller falls within range of average COP reported in similar works with single effect absorption chillers: Bolocan et al, (2015) reported a COP of 0.44 for a $5 \mathrm{~kW}$ capacity, Franchini et al., (2015) reported a COP of 0.358 for a $5 \mathrm{~kW}$ capacity, while Yin et al (2013) reported a COP of 0.38 for an $8 \mathrm{~kW}$ capacity. Average SCOP of about 0.1 was recorded for April $22^{\text {nd }}$, while average SCOP of 0.075 was recorded for June $8^{\text {th }}$. This indicates that in terms of the overall efficiency value of the solar cooling installation, the system performed better in April $22^{\text {nd }}$. This is attributed to the high solar radiation on April $22^{\text {nd }}$. 


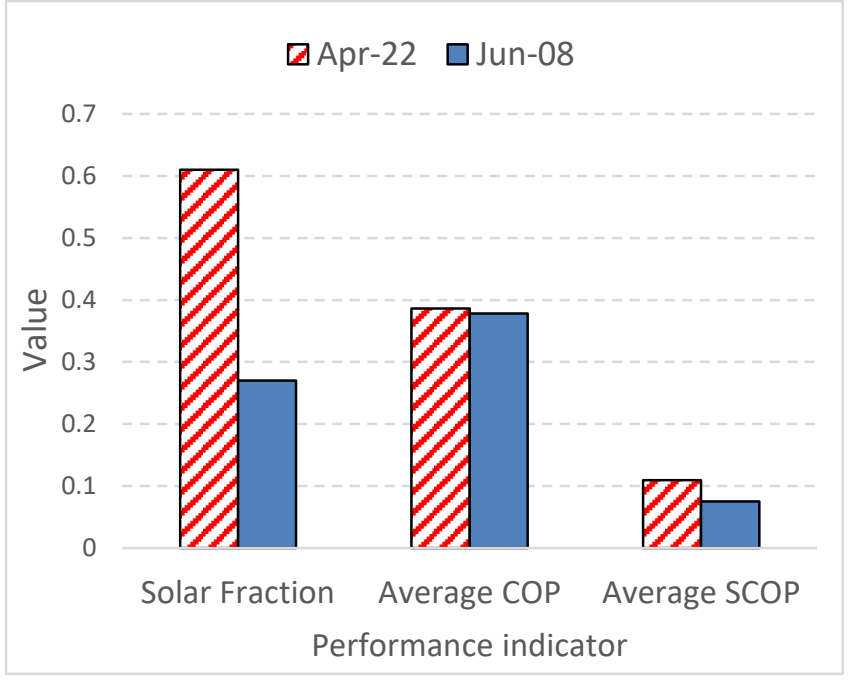

Fig. 15: Performance indicators for the experimental days.

\section{CONCLUSION}

An absorption air conditioning system of $3 \mathrm{~kW}$ capacity, operating on the lithium bromide/ water pair and powered by solar energy and LPG has been constructed and tested. Experiments conducted on a test room showed the chiller achieved a maximum COP of 0.439 and 0.427 on April 22 and June 8 respectively. The chiller attained a maximum cooling power of $1.47 \mathrm{~kW}$ and was able to cool the test room to within $24^{\circ} \mathrm{C}$ to $27^{\circ} \mathrm{C}$. Average solar fraction of 0.44 was attained for the two experimental days reported. Results compared favourably with those of similar works reported in literature.

\section{REFERENCES}

Balghouthi, M.; M. H. Chahbani and A. Guizani. (2012). Investigation of a solar cooling installation in Tunisia. Applied energy, 98: 138 - 148.

Bermejo, P.; F. Pino and F. Rosa. (2010). Solar absorption cooling plant in Seville. Solar energy, 54: 1503 1512.

Blackman, C.; C. Bales and E. Thorin. (2015). Techno - economic evaluation of solar - assisted heating and cooling systems with sorption module integrated solar collectors. Energy procedia, 70: 409 - 417.

Bolocan, S.; F. Chiriac; A. Serban and G. Dragomir. (2015). Development of a small capacity solar cooling absorption plant. Energy procedia, 74: $624-632$.
Demirel, Y. (2012). Energy, green energy and technology. Springer - Verlag, London ltd. Assessed from www.springer.com/cda/content on April 7, 2017.

Duffie,J.A. and Beckman, W.A. (2013). Solar engineering of thermal processes. $4^{\text {th }}$ Edition John Wiley and sons incorporation.

Eke, A. B. (2011). Prediction of optimum angle of inclination for flat plate solar collector in Zaria. CIGR Journal, 2: $1-10$.

Franchini, G.; E. Notarbartolo; L. Padovan and A. Perdichizzi. (2015). Modelling, design and construction of a micro scale absorption chiller. Energy procedia 82: $577-583$.

Gonzalez - Gil, A.; M. Izquierdo; J. D. Marcos and D. Palicios. (2011). Experimental evaluation of a direct air cooled Lithium Bromide - water absorption prototype for solar air conditioning. Applied thermal engineering (31), $3358-3368$.

Henning, H. (2007). Solar assisted air - conditioning of buildings, an overview. Applied thermal engineering, 27: 1734 -49 .

Kalkan, N.; E. A. Young and A. Celiktas. (2012). Solar thermal air conditioning technology reducing the foot print of solar thermal air conditioning. Renewable and sustainable energy reviews, 16: $6352-83$.

Ketjoy, N.; R. Yongphayoon and K. Mansiri. (2013). Performance evaluation of a $35 \mathrm{KW}$ lithium bromide - water solar absorption cooling system in Thailand. Energy procedia, 34: $198-210$.

Oyedepo, S. O. (2012). Energy and sustainable development in Nigeria: the way forward. Energy, Sustainability and Society. Springer open journal, 2(15): 1 17.

Sarbu, I. and Sebarchievici, C. (2015). General review of solar powered close sorption refrigeration systems. Energy conversion and management, 105: $403-442$.

Sun, H.; Z. Y. Xu; H. Wang and R. Wang. (2015). A solar/gas fired absorption system for cooling and heating in a commercial building. Energy procedia, 70: $518-528$.

Winston, R.; L. Jiang and B. Widyolar. (2014). Performance of a $23 \mathrm{~kW}$ solar thermal cooling system employing a double effect absorption chiller and thermodynamically efficient non tracking concentrators. Energy procedia, 48: 1036 - 1046.

Yin, Y. L.; X. Q. Zhai and R. Z. Wang. (2013). Experimental investigation and performance analysis of a mini type solar absorption cooling system. Applied thermal energy, 59: $267-277$. 